\title{
An improvement of two multi-criteria inventory classification models
}

\author{
Makram Ben Jeddou \\ Département Sciences Economiques et Gestion, Institut Supérieur des Etudes Technologiques de Radès, \\ BP 172-2098 Radès Médina-Tunisie.
}

\begin{abstract}
A B C$ analysis is a useful method to classify inventory items into different categories that can be specifically managed and controlled. Traditional ABC analysis classifies inventory items into three categories according to the annual dollar usage of an inventory item. Multi criteria inventory classification models have been proposed by researchers in order to take into account other important criteria. From these models we considered in this paper the $R$-model and the Ng-model in order to improve them. Illustrative examples are presented to compare the improved models and the initial ones. Keywords: $A B C$ classification, Multi criteria inventory classification models, $R$-model, $N g$-model.
\end{abstract}

\section{Literature review}

Companies often manage a large number of items. It is difficult to give all these items, the same level of monitoring and control. For this reason, managers should set priority levels for each category of items. Once this hierarchy established, we can assign specific business rules to each family of items. In this field, the $\mathrm{ABC}$ classification is mostly used by managers for inventory control. The classical $\mathrm{ABC}$ classification is based on the Pareto principle and according to the criterion of the annual use value. In fact, Class A items are relatively few in number (between 10\% and 20\%) but they represent between $70 \%$ and $80 \%$ of the total annual use value. The Class A items represents a great annual use value. For this reason, control of items of this class must be rigorous and tight. Class B contains between $30 \%$ and $40 \%$ of items that represent $15 \%$ to $20 \%$ of the total annual use value. The inventory control of class B items can be less tight than that of the first class A. Finally class C items can reach $50 \%$ of the items but represent only $5 \%$ to $10 \%$ in terms of value. Managers can reduce their effort in controlling these items because they are numerous but too small in terms of total annual use value.

When handling inventory classification, managers need to consider at the same time many important classification factors. Several Methodologies have been proposed in the literature for the multicriteria inventory classification problem (MCIC), but we will focus on the weighted optimization models. These models used a weighted additive function to aggregate the performance of an inventory item in terms of different criteria to a single score, called the inventory score of an item.

Ramanathan (2006) proposed a linear model which gives each item an opportunity to choose a set of weights favorable to the item itself when maximizing its score. To improve this model proposed by Ramanathan (2006), Zhou and Fan (2007) suggested a new classification based on a composite index. This score or index is a combination of a good index (maximizing score) and a bad index (minimizing score). The items classification will be then based on the calculated composite index. Ng (2007) proposed a linear programming model for the MCIC using a scalar measuring for all the criteria and with the main contribution of giving an importance order to the criteria. Hadi-Vencheh (2010) presented a nonlinear programming model as an extension version of the Ng-model. This model changed in the linear programming the constraint of the criterion weights by considering squared coefficients. Finally, Chen (2011) developed an improved approach to MCIC by which all items are peer-estimated. This new approach first determines two performance scores for each inventory item, then we determine a weight for each score in order to calculate a final aggregated index that will be used for the classification.

In this paper we will suggest firstly, a modified variant of R-model proposed by Ramanathan (2006) for MCIC. In this version, called $\mathrm{R}^{*}$-model, we consider the normalization step of the data to measure and analyze the impact of this pre-processing on the initial model. In the second part of this work, we will propose a new weighted linear optimization model which is an improvement of the $\mathrm{Ng}$ model developed by $\mathrm{Ng}$ (2007). This new model will be referred to as M-Ng model. 


\section{Impact of normalization step on the R-model}

In this section, we start by recalling the R-model.

$S_{i}=\operatorname{Max} \sum_{j=1}^{J} w_{i j} y_{i j}$

subject to

$\sum_{j=1}^{J} w_{i j} y_{n j} \leq 1 \quad \mathbf{n}=1,2 \ldots . . \mathrm{N}$

$\mathrm{w}_{\mathrm{ij}} \geq \mathrm{O} \quad \mathrm{j}=1,2 \ldots . \mathrm{J}$

The main objective of the normalization step is to eliminate the bias due to the unit effect. This transformation is considered as a pre-processing step in the weighted optimization multicriteria inventory models. This step plays a crucial role in standardizing scale measures of the $\mathrm{y}_{\mathrm{ij}} \forall \mathrm{i}=1, \ldots ., \mathrm{n} ; \forall \mathrm{j}=1, \ldots . . \mathrm{J}$ where $\mathrm{y}_{\mathrm{ij}}$ is the performance of the item $\mathrm{i}$ on the criterion $\mathrm{j}$. More formally, this step convert all the $\mathrm{y}_{\mathrm{ij}}$ in a 0 - 1 scale. They $y_{\mathrm{ij}} \forall \mathrm{i}=1, \ldots ., \mathrm{n} ; \forall \mathrm{j}=1, \ldots . . \mathrm{J}$, will be transformed on $\mathrm{y}_{\mathrm{ij}} \forall \mathrm{i}=1, \ldots ., \mathrm{n} ; \forall \mathrm{j}=1, \ldots . . \mathrm{J}$ by using the following expression :

$y_{i j}^{*}=\frac{y_{i j}-\min _{i=1, \ldots N}\left\{y_{i j}\right\}}{\max _{i=1, \ldots N}\left\{y_{i j}\right\}-\min _{i=1, \ldots N}\left\{y_{i j}\right\}}$

The proposed $\mathrm{R}^{*}$-model will then consider the normalized mesures $\mathrm{y}_{\mathrm{ij}}$ instead of the initials $\mathrm{y}_{\mathrm{ij}}$ as follows:

$S_{i}=\operatorname{Max} \sum_{j=1}^{J} w_{i j} y_{i j}^{*}$

subject to

$\sum_{j=1}^{J} w_{i j} y_{n j}^{*} \leq 1 \quad \mathrm{n}=1,2 \ldots . . \mathrm{N}$

$\mathrm{w}_{\mathrm{ij}} \geq 0 \quad \mathrm{j}=1,2 \ldots . . \mathrm{J}$

\section{Modified Ng-Model}

In this section firstly we recall the $\mathrm{Ng}$-model proposed by $\mathrm{Ng}$ (2007). Then we detailed the modifications made on this model in order to improve it.

\section{III.1. The Ng-Model}

To improve the quality of the inventory process, decision makers are needed to classify items using sophisticated and adequate methods. Generally these methods are based on advanced optimization backgrounds. In order to help the inventory managers in his inventory control and make it more easier, $\mathrm{Ng}(2007)$ proposes a multicriteria inventory classification model with a minimal mathematical background and without the use of an optimization solver. In fact $\mathrm{Ng}$-model provides the scores of inventory items without a linear optimizer.

Consider an inventory with $\mathrm{n}$ items must be classified based on $\mathrm{J}$ criteria. $\mathrm{y}_{\mathrm{ij}}$ : the measurement of the $\mathrm{i}^{\text {th }}$ item under the $\mathrm{j}^{\text {th }}$ criterion.

$\mathrm{w}_{\mathrm{ij}}$ : the non-negative weight represents the contribution of performance of the $\mathrm{i}^{\text {th }}$ item for the $\mathrm{j}^{\text {th }}$ criterion. $\mathrm{x}_{\mathrm{ij}}$ : the sum of the first $\mathrm{j}^{\text {th }} \mathrm{y}_{\mathrm{ij}}$ of the item $\mathrm{i}$.

$\mathrm{S}_{\mathrm{i}}$ : the score of the item $\mathrm{i}$.

$\mathrm{Z}_{\mathrm{i}}$ : the dual variable. 


$$
\begin{aligned}
& \operatorname{Max}_{i}=\sum_{j=1}^{J} w_{i j} y_{i j} \\
& \text { subject to } \\
& \sum_{j=1}^{J} w_{i j}=1 \\
& \mathrm{w}_{\mathrm{ij}}-w_{i(j+1)} \geq 0 \quad \mathrm{j}=1,2 \ldots \ldots, \mathrm{J}-1 \\
& \mathrm{w}_{\mathrm{ij}} \geq 0 \quad \mathrm{j}=1,2 \ldots \ldots \ldots, \mathrm{J}
\end{aligned}
$$

After two transformations of the $\mathrm{Ng}-$ Model, we obtain:

$$
S_{i}=\operatorname{Min} z_{i}=\operatorname{Max}_{j=1, \ldots \ldots .}\left(\frac{1}{j} x_{i j}\right)
$$

subject to

$z_{i} \geq \frac{1}{j} x_{i j} \quad j=1,2, \ldots \ldots . . J$

\section{III.2. Modified Ng-model (M-Ng model)}

The modified Ng-model is a two-phase model. The first phase is very similar to the original model but we remove the dominance order between the criteria. More precisely, we eliminate the following constraint in the linear model : $\mathrm{w}_{\mathrm{ij}}-\mathrm{w}_{\mathrm{i}(\mathrm{j}-1)} \geq 0$ in order to avoid the subjectiveness or in case of no consensus to set dominance order relations.

The second phase consists, firstly in computing the average weight of each criterion using weights generated by the original Ng-model. Secondly we use these obtained average weights to compute final score for each item. Finally, we classify items according to ABC principle and satisfying the constraint distribution. This second phase try to overcome the weakness of $\mathrm{Ng}$-model in considering independently each item when maximizing its score.

Consider an inventory with $\mathrm{n}$ items must be classified based on $\mathrm{J}$ criteria.

$y_{i j}$ : the measurement of the $i^{\text {th }}$ item under the $\mathrm{j}^{\text {th }}$ criterion.

$\mathrm{W}_{\mathrm{ij}}$ : the non- negative weight represents the contribution of performance of the $\mathrm{i}^{\text {th }}$ item for the $\mathrm{j}^{\text {th }}$ criterion.

$\mathrm{S}_{\mathrm{i}}$ : the score of the item $\mathrm{i}$.

\section{Phase I}

Step 1. A pre-processing procedure:

Convert all measurement $\mathrm{y}_{\mathrm{i}} \mathrm{j}$ in $0-1$ scale.

Compute for each item i $(\forall \mathrm{i}=1, \ldots, \mathrm{n})$ a normalized measure using the following transformation:

$$
y_{i j}^{*}=\frac{y_{i j}-\min _{i=1, \ldots N}\left\{y_{i j}\right\}}{\max _{i=1, \ldots N}\left\{y_{i j}\right\}-\min _{i=1, \ldots N}\left\{y_{i j}\right\}}
$$

Step 2. Weights generation procedure:

For each item i $(\forall \mathrm{i}=1, \ldots, \mathrm{n})$

$$
\operatorname{Max} S_{i}=\sum_{j=1}^{J} w_{i j} y_{i j}^{*}
$$

subject to

$\sum_{j=1}^{J} w_{i j}=1$

$$
\mathrm{w}_{\mathrm{ij}} \geq 0 \quad \mathrm{j}=1,2 \ldots . . \mathrm{J}
$$




\section{Phase II}

Step 1. Average weights computing

$$
\bar{w}_{i j}=\frac{\sum_{i=1}^{n} w_{i j}}{n} \quad j=1,2 \ldots . ., J
$$

Step 2. Final scores

$$
S_{i}^{\prime}=\sum_{j=1}^{J} \bar{w}_{i j} y_{i j}^{*} \quad i=1,2 \ldots . ., n
$$

\section{Step 3. The classification}

Sort the scalar scores $\mathrm{S}_{i}$ in the descending order. Then Group the inventory items by the principle of the $\mathrm{ABC}$ analysis

\section{Computational results}

In order to illustrate and compare the performance of our proposed models to the R-Model and the $\mathrm{Ng}$-Model, we apply it to the MCIC problem using the 47 benchmark inventory items presented in Flores et al (1992). Our experimental study is based on the following four criteria: average unit cost, annual dollar usage, lead time and critical factor. More precisely, we add the critical factor criterion in the $\mathrm{Ng}$-model while considering the old dominance constraint and considering also that the critical factor is dominated by the three others criteria. As in the previous studies we maintain the same distribution of 10-class A items, 14class B items and 23-class $\mathrm{C}$ items. It should be noted that all the considered criteria are positively related to the importance degree called score of the inventory items.

\section{IV.1. Performance of the $\mathbf{R} *$ model}

In this section, we present a comparison between the R-model and the $\mathrm{R}^{*}$-model using normalization. As shown in table 1, we note a difference between the two models. In fact, the percentage of items correctly classified by the two models is $40 \%$. The detailed benchmarking by class suggests differences between the three classes in terms of percentage of items correctly classified by the two models. This percentage is relatively high for class C (57\%). For classes A and B respectively $30 \%$ and $21 \%$ of items are similarly classified by the R-model and the $\mathrm{R}^{*}$-model.

The new classification according to the $\mathrm{R}^{*}$-model is structured as follows. The new class $\mathrm{A}$ is composed by 3 items $(15,29$ and 34) similarly classified by the old R-model. The remaining seven items were over classified from class B to A (items 1 and 23) and from class $\mathrm{C}$ to A (items 9, 13, 32, 2 and 3).

The new class B in the $\mathrm{R}^{*}$ model maintains the same 3 items 21, 31 and 40. Items 4, 14, 18, 19, 28 and 45 were under classified from class A to B. However, five items (10, 11, 12, 24 and 36) jumped from class $\mathrm{C}$ to $\mathrm{B}$. In the last class $\mathrm{C}$, we find that 13 items are identically classified as in the R-model. Item 16 is dropped down from class A to C. Nine other items (17, 22, 27, 33,37, 39, 47, 20 and 43) are under classified from class B to C. The detailed obtained results are depicted in table 2 .

\section{IV.2. Performance of the M-Ng model}

In this section, firstly we present a comparison between the $\mathrm{Ng}$-model and the modified one. Then we will analyze conflicts between $\mathrm{R}$-model and the $\mathrm{Ng}$-model that are solved by the $\mathrm{M}-\mathrm{Ng}$ model. As shown in table 3, we notice a significant difference between $\mathrm{Ng}$ and $\mathrm{M}-\mathrm{Ng}$ models. In fact, the percentage of items correctly classified by the two models is $60 \%$. In the detailed benchmarking by class, we notice relevant differences between the three classes in terms of percentage of items correctly classified by the two models. This percentage is high for class C (74\%) but decreases to $50 \%$ for items of class A and to $43 \%$ for those of class B.

The five items: 18, 23, 21, 14 and 45 belonging to class B in the Ng-model jumped to the first class A when using the modified $\mathrm{Ng}$-model. The $\mathrm{M}-\mathrm{Ng}$ model over classifies also six items $(34,12,40,22,20$ and 17) from class $\mathrm{C}$ to the second class $\mathrm{B}$. On the other hand, items 10 and 1 assigned to class $\mathrm{A}$ in the $\mathrm{Ng}$ model are demoted to class B when using the new classifying model. Finally, we notice also in the modified $\mathrm{Ng}$ - model that 6 items $(5,6,4,32,7$ and 8) from classes A and B in the original Ng-model, are under classified in the class $\mathrm{C}$.

The obtained detailed results are depicted in table 4 . 


\section{IV.3. Conflict handling}

As shown in Table 4, there are 31 items that have been classified by the $\mathrm{Ng}$-Model and the R-Model in opposite classes. The proposed $\mathrm{M}-\mathrm{Ng}$ model settles these conflicts by assigning a class suggested by one of the two models in 29 cases out of 31 or giving a totally different class in 2 cases out of 31 . In the first 29 handled conflicts, the M-Ng model chooses for 16 items 2, 3, 9, 13,15, 16, 19, 24, 27, 28, 33, 36, 37, 39, 43 and 47 the same classification given by the $\mathrm{Ng}$-model, but chooses for the other 13 items 1, 5, 6, 7, 8, 14, 17, 18, 20, 22, 32, 40 and 45, the same class assignment given by the R-model.

On the other hand, for items 34 and 10 classified by the $\mathrm{Ng-Model} \mathrm{and} \mathrm{the} \mathrm{R-Model} \mathrm{in} \mathrm{op-} \mathrm{posite} \mathrm{classes} \mathrm{A} \mathrm{and}$ $\mathrm{C}$, the $\mathrm{M}-\mathrm{Ng}$ model attributes them the medium class B.

\section{Conclusion}

In this paper, improved models for multi-criteria inventory classification are proposed. In fact, the first contribution of this work is to analyze the effect of using normalized data in the R-model. This new $\mathrm{R}^{*}$ model leads to $60 \%$ difference in items classification. The second contribution of this paper is the improvement of the $\mathrm{Ng}$ model used in the $\mathrm{MCIC}$ by proposing a new model called $\mathrm{M}-\mathrm{Ng}$ model. This new model presents significant differences compared to initial $\mathrm{Ng}$-model and also handles classification conflicts between the $\mathrm{R}$ and $\mathrm{Ng}$ models. One way to extend this research is to apply and compare our improved models using larger data sets for MCIC.

\section{References}

[1]. Chen J. 2011. Peer-estimation for multiple criteria ABC inventory classification, Computers \& Operations Research, 38, 17841791.

[2]. Flores, B. E., Olson, D. L., \& Dorai, V. K. 1992. Management of multicriteria inventory classification. Mathematical and Computer Modeling, 16,71-82.

[3]. Hadi-Vencheh A. 2010. An improvement to multiple criteria ABC inventory classification. European Journal of Operational Research, 201, 962-965.

[4]. Ng W. L. 2007. A simple classifier for multiple criteria ABC analysis, European Journal of Operational Research, 177, 344-353.

[5]. Ramanathan R. 2006. ABC inventory classification with multiple-criteria using weighted linear optimization, Computers and Operations Research,33, 695-700.

[6]. Zhou P., \& Fan L. 2007. A note on multi-criteria ABC inventory classification using weighted linear optimization, European Journal of Operational Research, 182, 1488-1491.

Table 1: Concordance between $\mathrm{R}$ and $\mathrm{R}^{*}$ models classification

\begin{tabular}{|l|c|c|c|c|}
\hline & Class A & Class B & Class C & Total \\
\hline $\begin{array}{l}\text { Number of items correctly classified } \\
\text { by the two models (R and R*) }\end{array}$ & 3 & 3 & 13 & 19 \\
\hline $\begin{array}{l}\text { Percentage of items correctly classified } \\
\text { by the two models (R and R*) }\end{array}$ & $30 \%$ & $21 \%$ & $57 \%$ & $40 \%$ \\
\hline
\end{tabular}

Table 2: A comparison of $\mathrm{ABC}$ classification using $\mathrm{R}$ and $\mathrm{R}$ * models

\begin{tabular}{|c|c|c|c|c|c|c|c|c|c|c|c|}
\hline \multirow[b]{2}{*}{$\begin{array}{c}\text { Item } \\
\text { no }\end{array}$} & \multicolumn{4}{|c|}{ Initial data } & \multicolumn{4}{|c|}{ Normalized data } & & \multicolumn{2}{|c|}{$\begin{array}{c}\mathrm{ABC} \\
\text { classification }\end{array}$} \\
\hline & $\begin{array}{c}\text { Average } \\
\text { unit } \\
\operatorname{cost}(\$)\end{array}$ & $\begin{array}{c}\text { Annual } \\
\text { dollar } \\
\text { usage }(\$)\end{array}$ & $\begin{array}{l}\text { Lead } \\
\text { time }\end{array}$ & $\begin{array}{l}\text { Critical } \\
\text { factor }\end{array}$ & $\begin{array}{c}\text { Average } \\
\text { unit } \\
\operatorname{cost}(\$)\end{array}$ & $\begin{array}{c}\text { Annual } \\
\text { dollar } \\
\text { usage }\end{array}$ & $\begin{array}{l}\text { Lead } \\
\text { time }\end{array}$ & $\begin{array}{l}\text { Critical } \\
\text { factor }\end{array}$ & Score & $\begin{array}{c}\mathrm{R}^{*} \\
\text { model }\end{array}$ & $\begin{array}{c}\mathrm{R} \\
\text { model }\end{array}$ \\
\hline 15 & 71,2 & 854,4 & 3 & 1 & 0,32 & 0,14 & 0,33 & 1,00 & 1,00 & A & A \\
\hline 29 & 134,34 & 268,68 & 7 & 0,01 & 0,63 & 0,04 & 1,00 & 0,00 & 1,00 & A & A \\
\hline 34 & 7,07 & 190,89 & 7 & 0,01 & 0,01 & 0,03 & 1,00 & 0,00 & 1,00 & A & A \\
\hline 1 & 49,92 & 5840,64 & 2 & 1 & 0,22 & 1,00 & 0,17 & 1,00 & 1,00 & A & B \\
\hline 23 & 86,5 & 432,5 & 4 & 1 & 0,40 & 0,07 & 0,50 & 1,00 & 1,00 & A & B \\
\hline 2 & 210 & 5670 & 5 & 1 & 1,00 & 0,97 & 0,67 & 1,00 & 1,00 & A & $\mathrm{C}$ \\
\hline
\end{tabular}


Table 2 - continue

\begin{tabular}{|c|c|c|c|c|c|c|c|c|c|c|c|}
\hline & \multicolumn{4}{|c|}{ Initial data } & \multicolumn{4}{|c|}{ Normalized data } & & \multicolumn{2}{|c|}{$\begin{array}{c}\mathrm{ABC} \\
\text { classification }\end{array}$} \\
\hline $\begin{array}{c}\text { Item } \\
\text { no }\end{array}$ & $\begin{array}{c}\text { Average } \\
\text { unit cost }(\$)\end{array}$ & $\begin{array}{c}\text { Annual } \\
\text { dollar } \\
\text { usage }(\$)\end{array}$ & $\begin{array}{l}\text { Lead } \\
\text { time }\end{array}$ & $\begin{array}{l}\text { Critical } \\
\text { factor }\end{array}$ & $\begin{array}{c}\text { Average } \\
\text { unit cost }(\$)\end{array}$ & $\begin{array}{c}\text { Annual } \\
\text { dollar } \\
\text { usage }\end{array}$ & $\begin{array}{l}\text { Lead } \\
\text { time }\end{array}$ & $\begin{array}{c}\text { Critical } \\
\text { factor }\end{array}$ & Score & $\begin{array}{c}\mathrm{R}^{*} \\
\text { model }\end{array}$ & $\begin{array}{c}\mathrm{R} \\
\text { model }\end{array}$ \\
\hline 3 & 23,76 & 5037,12 & 4 & 1 & 0,09 & 0,86 & 0,50 & 1,00 & 1,00 & $\mathrm{~A}$ & $\mathrm{C}$ \\
\hline 9 & 73,44 & 2423,52 & 6 & 1 & 0,33 & 0,41 & 0,83 & 1,00 & 1,00 & A & $\mathrm{C}$ \\
\hline 13 & 86,5 & 1038 & 7 & 1 & 0,40 & 0,17 & 1,00 & 1,00 & 1,00 & A & $\mathrm{C}$ \\
\hline 32 & 53,02 & 212,08 & 2 & 1 & 0,23 & 0,03 & 0,17 & 1,00 & 1,00 & A & $\mathrm{C}$ \\
\hline 4 & 27,73 & 4769,56 & 1 & 0,01 & 0,11 & 0,82 & 0,00 & 0,00 & 0,82 & B & A \\
\hline 14 & 110,4 & 883,2 & 5 & 0,5 & 0,51 & 0,15 & 0,67 & 0,49 & 0,75 & B & $\mathrm{A}$ \\
\hline 18 & 49,5 & 594 & 6 & 0,5 & 0,22 & 0,10 & 0,83 & 0,49 & 0,83 & B & A \\
\hline 19 & 47,5 & 570 & 5 & 0,5 & 0,21 & 0,09 & 0,67 & 0,49 & 0,67 & B & A \\
\hline 28 & 78,4 & 313,6 & 6 & 0,01 & 0,36 & 0,05 & 0,83 & 0,00 & 0,83 & B & A \\
\hline 45 & 34,4 & 34,4 & 7 & 0,01 & 0,14 & 0,00 & 1,00 & 0,00 & 1,00 & B & A \\
\hline 21 & 24,4 & 463,6 & 4 & 1 & 0,09 & 0,08 & 0,50 & 1,00 & 1,00 & B & B \\
\hline 31 & 72 & 216 & 5 & 0,5 & 0,33 & 0,03 & 0,67 & 0,49 & 0,68 & B & B \\
\hline 40 & 51,68 & 103,36 & 6 & 0,01 & 0,23 & 0,01 & 0,83 & 0,00 & 0,83 & B & B \\
\hline 10 & 160,5 & 2407,5 & 4 & 0,5 & 0,76 & 0,41 & 0,50 & 0,49 & 0,76 & B & $\mathrm{C}$ \\
\hline 11 & 5,12 & 1075,2 & 2 & 1 & 0,00 & 0,18 & 0,17 & 1,00 & 1,00 & B & $\mathrm{C}$ \\
\hline 12 & 20,87 & 1043,5 & 5 & 0,5 & 0,08 & 0,18 & 0,67 & 0,49 & 0,69 & B & $\mathrm{C}$ \\
\hline 24 & 33,2 & 398,4 & 3 & 1 & 0,14 & 0,06 & 0,33 & 1,00 & 1,00 & B & $\mathrm{C}$ \\
\hline 36 & 40,82 & 163,28 & 3 & 1 & 0,17 & 0,02 & 0,33 & 1,00 & 1,00 & B & $\mathrm{C}$ \\
\hline 16 & 45 & 810 & 3 & 0,5 & 0,19 & 0,13 & 0,33 & 0,49 & 0,49 & $\mathrm{C}$ & A \\
\hline 17 & 14,66 & 703,68 & 4 & 0,5 & 0,05 & 0,12 & 0,50 & 0,49 & 0,51 & $\mathrm{C}$ & B \\
\hline 20 & 58,45 & 467,6 & 4 & 0,5 & 0,26 & 0,08 & 0,50 & 0,49 & 0,52 & $\mathrm{C}$ & B \\
\hline 22 & 65 & 455 & 4 & 0,5 & 0,29 & 0,07 & 0,50 & 0,49 & 0,54 & $\mathrm{C}$ & B \\
\hline 27 & 84,03 & 336,12 & 1 & 0,01 & 0,39 & 0,05 & 0,00 & 0,00 & 0,39 & $\mathrm{C}$ & B \\
\hline 33 & 49,48 & 197,92 & 5 & 0,01 & 0,22 & 0,03 & 0,67 & 0,00 & 0,67 & $\mathrm{C}$ & B \\
\hline 37 & 30 & 150 & 5 & 0,01 & 0,12 & 0,02 & 0,67 & 0,00 & 0,67 & $\mathrm{C}$ & B \\
\hline 39 & 59,6 & 119,2 & 5 & 0,01 & 0,27 & 0,02 & 0,67 & 0,00 & 0,67 & $\mathrm{C}$ & B \\
\hline 43 & 29,89 & 59,78 & 5 & 0,01 & 0,12 & 0,01 & 0,67 & 0,00 & 0,67 & $\mathrm{C}$ & B \\
\hline 47 & 8,46 & 25,38 & 5 & 0,01 & 0,02 & 0,00 & 0,67 & 0,00 & 0,67 & $\mathrm{C}$ & B \\
\hline 5 & 57,98 & 3478,8 & 3 & 0,5 & 0,26 & 0,59 & 0,33 & 0,49 & 0,61 & $\mathrm{C}$ & $\mathrm{C}$ \\
\hline 6 & 31,24 & 2936,67 & 3 & 0,5 & 0,13 & 0,50 & 0,33 & 0,49 & 0,52 & $\mathrm{C}$ & C \\
\hline 7 & 28,2 & 2820 & 3 & 0,5 & 0,11 & 0,48 & 0,33 & 0,49 & 0,50 & $\mathrm{C}$ & $\mathrm{C}$ \\
\hline 8 & 55 & 2640 & 4 & 0,01 & 0,24 & 0,45 & 0,50 & 0,00 & 0,64 & $\mathrm{C}$ & $\mathrm{C}$ \\
\hline 25 & 37,05 & 370,5 & 1 & 0,01 & 0,16 & 0,06 & 0,00 & 0,00 & 0,16 & $\mathrm{C}$ & $\mathrm{C}$ \\
\hline 26 & 33,84 & 338,4 & 3 & 0,01 & 0,14 & 0,05 & 0,33 & 0,00 & 0,33 & $\mathrm{C}$ & $\mathrm{C}$ \\
\hline 30 & 56 & 224 & 1 & 0,01 & 0,25 & 0,03 & 0,00 & 0,00 & 0,25 & $\mathrm{C}$ & $\mathrm{C}$ \\
\hline 35 & 60,6 & 181,8 & 3 & 0,01 & 0,27 & 0,03 & 0,33 & 0,00 & 0,37 & $\mathrm{C}$ & $\mathrm{C}$ \\
\hline 38 & 67,4 & 134,8 & 3 & 0,5 & 0,30 & 0,02 & 0,33 & 0,49 & 0,49 & $\mathrm{C}$ & $\mathrm{C}$ \\
\hline 41 & 19,8 & 79,2 & 2 & 0,01 & 0,07 & 0,01 & 0,17 & 0,00 & 0,17 & $\mathrm{C}$ & $\mathrm{C}$ \\
\hline 42 & 37,7 & 75,4 & 2 & 0,01 & 0,16 & 0,01 & 0,17 & 0,00 & 0,20 & $\mathrm{C}$ & $\mathrm{C}$ \\
\hline 44 & 48,3 & 48,3 & 3 & 0,01 & 0,21 & 0,00 & 0,33 & 0,00 & 0,33 & $\mathrm{C}$ & $\mathrm{C}$ \\
\hline 46 & 28,8 & 28,8 & 3 & 0,01 & 0,12 & 0,00 & 0,33 & 0,00 & 0,33 & $\mathrm{C}$ & $\mathrm{C}$ \\
\hline
\end{tabular}

Table 3: Concordance between $\mathrm{Ng}$ and $\mathrm{M}-\mathrm{Ng}$ models classification

\begin{tabular}{|l|c|c|c|c|}
\hline & Class A & Class B & Class C & Total \\
\hline $\begin{array}{l}\text { Number of items correctly classified } \\
\text { by the two models (Ng and M-Ng) }\end{array}$ & 5 & 6 & 17 & 28 \\
\hline $\begin{array}{l}\text { Percentage of items correctly classified } \\
\text { by the two models (Ng and M-Ng) }\end{array}$ & $50 \%$ & $43 \%$ & $74 \%$ & $60 \%$ \\
\hline
\end{tabular}


Table 4: A comparison of ABC classification using $\mathrm{M}-\mathrm{Ng}, \mathrm{Ng}$ and $\mathrm{R}$ models

\begin{tabular}{|c|c|c|c|c|c|c|c|c|}
\hline \multirow[b]{2}{*}{$\begin{array}{c}\text { Item } \\
\text { no }\end{array}$} & \multirow[b]{2}{*}{$\begin{array}{l}\text { Average unit } \\
\operatorname{cost}(\$)\end{array}$} & \multirow[b]{2}{*}{$\begin{array}{c}\text { Annual } \\
\text { dollar } \\
\text { usage }(\$)\end{array}$} & \multirow[b]{2}{*}{$\begin{array}{l}\text { Lead } \\
\text { time }\end{array}$} & \multirow[b]{2}{*}{$\begin{array}{l}\text { Critical } \\
\text { factor }\end{array}$} & \multirow[b]{2}{*}{$\begin{array}{c}\text { optimal } \\
\text { Inventory } \\
\text { score } \\
\end{array}$} & \multicolumn{3}{|c|}{$\mathrm{ABC}$ classification } \\
\hline & & & & & & $\begin{array}{l}\text { M-Ng } \\
\text { Model }\end{array}$ & $\begin{array}{c}\mathrm{Ng} \\
\text { Model }\end{array}$ & R Model \\
\hline 2 & 0,97 & 1,00 & 0,67 & 1,00 & 0,817 & $\mathrm{~A}$ & $\mathrm{~A}$ & $\mathrm{C}$ \\
\hline 3 & 0,86 & 0,09 & 0,50 & 1,00 & 0,631 & A & A & $\mathrm{C}$ \\
\hline 9 & 0,41 & 0,33 & 0,83 & 1,00 & 0,802 & A & A & $\mathrm{C}$ \\
\hline 13 & 0,17 & 0,40 & 1,00 & 1,00 & 0,881 & A & A & $\mathrm{C}$ \\
\hline 14 & 0,15 & 0,51 & 0,67 & 0,49 & 0,564 & A & $\mathrm{B}$ & A \\
\hline 18 & 0,10 & 0,22 & 0,83 & 0,49 & 0,622 & A & B & A \\
\hline 21 & 0,08 & 0,09 & 0,50 & 1,00 & 0,573 & $\mathrm{~A}$ & B & $\mathrm{B}$ \\
\hline 23 & 0,07 & 0,40 & 0,50 & 1,00 & 0,602 & A & B & B \\
\hline 29 & 0,04 & 0,63 & 1,00 & 0,00 & 0,606 & A & A & A \\
\hline 45 & 0,00 & 0,14 & 1,00 & 0,00 & 0,556 & A & B & A \\
\hline 1 & 1,00 & 0,22 & 0,17 & 1,00 & 0,473 & B & A & B \\
\hline 10 & 0,41 & 0,76 & 0,50 & 0,49 & 0,517 & B & A & $\mathrm{C}$ \\
\hline 12 & 0,18 & 0,08 & 0,67 & 0,49 & 0,524 & B & $\mathrm{C}$ & $\mathrm{C}$ \\
\hline 15 & 0,14 & 0,32 & 0,33 & 1,00 & 0,510 & B & B & A \\
\hline 17 & 0,12 & 0,05 & 0,50 & 0,49 & 0,427 & B & $\mathrm{C}$ & B \\
\hline 19 & 0,09 & 0,21 & 0,67 & 0,49 & 0,531 & B & B & A \\
\hline 20 & 0,08 & 0,26 & 0,50 & 0,49 & 0,444 & B & $\mathrm{C}$ & B \\
\hline 22 & 0,07 & 0,29 & 0,50 & 0,49 & 0,447 & B & $\mathrm{C}$ & B \\
\hline 24 & 0,06 & 0,14 & 0,33 & 1,00 & 0,486 & B & B & $\mathrm{C}$ \\
\hline 28 & 0,05 & 0,36 & 0,83 & 0,00 & 0,490 & B & B & A \\
\hline 31 & 0,03 & 0,33 & 0,67 & 0,49 & 0,538 & B & B & B \\
\hline 34 & 0,03 & 0,01 & 1,00 & 0,00 & 0,546 & B & $\mathrm{C}$ & A \\
\hline 36 & 0,02 & 0,17 & 0,33 & 1,00 & 0,487 & B & B & $\mathrm{C}$ \\
\hline 40 & 0,01 & 0,23 & 0,83 & 0,00 & 0,475 & B & $\mathrm{C}$ & B \\
\hline 4 & 0,82 & 0,11 & 0,00 & 0,00 & 0,071 & $\mathrm{C}$ & A & A \\
\hline 5 & 0,59 & 0,26 & 0,33 & 0,49 & 0,392 & $\mathrm{C}$ & A & $\mathrm{C}$ \\
\hline 6 & 0,50 & 0,13 & 0,33 & 0,49 & 0,373 & $\mathrm{C}$ & A & $\mathrm{C}$ \\
\hline 7 & 0,48 & 0,11 & 0,33 & 0,49 & 0,370 & $\mathrm{C}$ & B & $\mathrm{C}$ \\
\hline 8 & 0,45 & 0,24 & 0,50 & 0,00 & 0,328 & $\mathrm{C}$ & B & $\mathrm{C}$ \\
\hline 11 & 0,18 & 0,00 & 0,17 & 1,00 & 0,391 & $\mathrm{C}$ & $\mathrm{C}$ & $\mathrm{C}$ \\
\hline 16 & 0,13 & 0,19 & 0,33 & 0,49 & 0,352 & $\mathrm{C}$ & $\mathrm{C}$ & A \\
\hline 25 & 0,06 & 0,16 & 0,00 & 0,00 & 0,019 & $\mathrm{C}$ & $\mathrm{C}$ & $\mathrm{C}$ \\
\hline 26 & 0,05 & 0,14 & 0,33 & 0,00 & 0,198 & $\mathrm{C}$ & $\mathrm{C}$ & $\mathrm{C}$ \\
\hline 27 & 0,05 & 0,39 & 0,00 & 0,00 & 0,041 & $\mathrm{C}$ & $\mathrm{C}$ & B \\
\hline 30 & 0,03 & 0,25 & 0,00 & 0,00 & 0,026 & $\mathrm{C}$ & $\mathrm{C}$ & $\mathrm{C}$ \\
\hline 32 & 0,03 & 0,23 & 0,17 & 1,00 & 0,402 & $\mathrm{C}$ & B & $\mathrm{C}$ \\
\hline 33 & 0,03 & 0,22 & 0,67 & 0,00 & 0,385 & $\mathrm{C}$ & $\mathrm{C}$ & B \\
\hline 35 & 0,03 & 0,27 & 0,33 & 0,00 & 0,209 & $\mathrm{C}$ & $\mathrm{C}$ & $\mathrm{C}$ \\
\hline 37 & 0,02 & 0,12 & 0,67 & 0,00 & 0,375 & $\mathrm{C}$ & $\mathrm{C}$ & B \\
\hline 38 & 0,02 & 0,30 & 0,33 & 0,49 & 0,354 & $\mathrm{C}$ & $\mathrm{C}$ & $\mathrm{C}$ \\
\hline 39 & 0,02 & 0,27 & 0,67 & 0,00 & 0,388 & $\mathrm{C}$ & $\mathrm{C}$ & B \\
\hline 41 & 0,01 & 0,07 & 0,17 & 0,00 & 0,098 & $\mathrm{C}$ & $\mathrm{C}$ & $\mathrm{C}$ \\
\hline 42 & 0,01 & 0,16 & 0,17 & 0,00 & 0,106 & $\mathrm{C}$ & $\mathrm{C}$ & $\mathrm{C}$ \\
\hline 43 & 0,01 & 0,12 & 0,67 & 0,00 & 0,374 & $\mathrm{C}$ & $\mathrm{C}$ & B \\
\hline 44 & 0,00 & 0,21 & 0,33 & 0,00 & 0,201 & $\mathrm{C}$ & $\mathrm{C}$ & $\mathrm{C}$ \\
\hline 46 & 0,00 & 0,12 & 0,33 & 0,00 & 0,192 & $\mathrm{C}$ & $\mathrm{C}$ & $\mathrm{C}$ \\
\hline 47 & 0,00 & 0,02 & 0,67 & 0,00 & 0,363 & $\mathrm{C}$ & $\mathrm{C}$ & B \\
\hline
\end{tabular}

